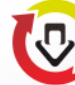

Check for updates

\section{Audit Quality: Does Time Pressure Influence Independence and Audit Procedure Compliance of Auditor?}

\author{
Firda Ayu Amalia*1, Sutrisno², Zaki Baridwan²
}

\begin{abstract}
This research was aimed to empirically examine the effect of independence and audit procedure on audit quality with time budget pressure as moderator variable. The population comprised auditors working on Public Accountant Office (KAP) in East Java, while the samples consisted of 45 respondents. This study used a survey technique is by questionnaire as data collection techniques. The PLS was used for data analysis. The result showed that the independence and audit procedure positively affected the audit quality. The variable of time budget pressure as moderator was capable to enfeeble the relation between the independence and audit quality, and also to reinforce the relation between audit procedure and audit quality. The results of this study have provided support for Agency theory. A quality audit can reduce information asymmetry so as to minimize moral hazard actions by management.
\end{abstract}

KEYWORDS: independence; audit procedure; time pressure; audit quality

\section{Introduction}

Research on audit quality is motivated by a decline in audit quality. An audit is said to be of quality if the opinion issued by the auditor reflects the actual condition of the company. However, several audit failure cases that have occurred in several countries, especially in Indonesia reflect audits that have decreased quality. Every year there is always a freeze on licenses of several public accountants by the Ministry of Finance because they have not carried out audits in accordance with audit standards. This has a significant influence on opinion reflected in the independent auditor's report (pppk-kemenkeu, 2018). For example, Rolls Royce aircraft engine manufacturers in the UK received a fine of GBP 671 million. This fine is related to granting bribes to executives of buyers of Rolls Royce products. In the Rolls Royce case, an investigation of KPMG which became the Rolls Royce auditor began. Public questions are how auditors can publish reports or opinions, in fact they fail to find something wrong in the body of the organization being audited (Priantara, 2017).

Copyright: (c) 2019 Amalia, Sutrisno \& Baridwan. This is an open access article distributed under the terms of the Creative Commons Attribution License, which permits unrestricted use, distribution, and reproduction in any medium, provided the original author and source are credited.
Consistent with audit failures in the UK, in Indonesia the Marlinna Public Accountant (AP), Merliyana Syamsul, and Public Accountant Office (KAP) Satrio Bing, Eny \& Rekan (Deloitte Indonesia) were subject to sanctions for violations of the audit professional standards, especially audit procedures. The results of the examination by the Center for Financial Professional Development (PPPK) concluded that Marlinna and Merliyana Syamsul Public Accountants had not fully complied with the Audit Standards Professional Standards of Public Accountants in the implement-tation of general audits of PT. Sunprima Nusantara Financing (SNP Finance) fiscal year 2012 to 2016 . Besides, the quality control system possessed by KAP 
contains weaknesses because it has not been able to properly prevent the threat of closeness in the form of a long enough relationship between senior personnel (audit team manager) in the audit engagement for the same client for a long period of time. So that it can be concluded that violations committed related to audit procedures in detecting fraud and auditor independence (pppk-kemenkeu, 2018).

In addition, there is more news that the Public Company Accounting Oversight Board (PCAOB) or the Board of Trustees of the United States of America (US) has sentenced the Public Accounting Firm (KAP) Purwanto, Suherman and Surja along with Ernst and Young (EY) Indonesia partners for proved to be instrumental in the failure of PT Indosat Tbk's financial statement audit in 2011. Provision of Unqualified Opinion (WTP) opinion by auditors is not supported by sufficient and adequate evidence in the implementation of audit procedures. It can be said that there is a violation of audit standards by the auditor. The penalty given by PCAOB was a fine of US $\$ 1$ million to Ernst and Young Indonesia. Then the fine was also given to public accountants who were EY Indonesia's partners, namely Roy Iman Wirahardja for US $\$ 20,000$ plus a ban on practicing for five years (Ashari, 2017).

In Indonesia, in response to the decline in audit quality, the Professional Accountants Committee recommends setting audit quality indicators to the Public Accountants Association and the Center for Financial Professional Development. The purpose of the draft audit quality indicators is to improve the quality of audit services, increase public trust in the practice of the public accounting profession, and respond to global developments that demand audit according to international best practices (IAPI, 2016). The draft contains audit quality indicators which include auditor competence, ethics and auditor independence, time usage of key engagement personnel, quality control systems, quality review results or external and internal party inspections, range of control arrangements, organization and governance of $\mathrm{KAP}$, and finally policy recompense.

Audit quality is important because financial reports that are quality and free from misstatements result from quality audits (Sudarna \& Ludigdo, 2014). The possibility that the auditor will find misstatements does not only depend on the quality of the auditor's understanding (competence) but also on the independence of the auditor to report the misstatement (Rahmina \& Agoes, 2014). Many previous studies have examined the effect of independence on audit quality such as Rahmina and Agoes (2014), Septriani (2012) and Amrulloh and Putra (2014). These studies focused on independence in mind (independence in mind) and independence in appearance (independence in appearance). The current research adds independence criteria as the auditor's partisanship to dare to report findings in the audit process. Or it can be said that auditors must have independence in expertise.

Independence in the expertise of an auditor can improve audit quality if supported by audit procedures. The selection of audit procedures was motivated by the case of SNP Finance in Indonesia and Rolls Royce in the UK, as mentioned earlier. Actually, the case was caused by no disclosure of fraud in the audit process. The procedure of the audit carried out cannot reveal the existence of fraudulent actions, so the researcher refers to the research 
of Sarwoko and Agoes (2014). The reason for referring to the research of is the audit procedure indicator in the study referring to SAS 99 (Sarwoko \& Agoes, 2014). The indicator used by researchers regarding audit procedures is whether auditors carry out SAS 99 or not. Standard audit SAS 99 regarding the consideration of fraud in the financial statements. Auditor is responsible for planning and carrying out audits to obtain sufficient confidence whether the financial statements are free from material errors and whether there are intentional or not errors (AICPA, 2014).

The researcher added the time pressure moderation variable in examining the relationship of independence and audit procedures to audit quality. The addition of this moderation variable is because time pressure is one indicator that affects audit quality (IAPI, 2016). The addition of time pressure variables as moderating variables was carried out by Halim (2014), Gasperz (2014) and Pradipta and Budiartha (2016). The results of the three studies are inconsistent. Time pressure cannot moderate the relationship of professionalism, auditor experience and audit quality (Pradipta \& Budiartha, 2016). Gasperz (2014) explains that time pressure can moderate the relationship between accountability, ethical awareness and quality, but pressure cannot moderate the relationship of independence and audit quality.

The difference in this research with previous research also lies in the basis of the theory used. The researcher uses the basis of inverse $U$ theory, namely the theory of work stress as the theoretical basis for the time pressure moderation variable (Wijono, 2010). In the theory, it is explained that when a person gets a stimulus that is too low or too high, the performance or performance produced will be low. However, when a given stimulus reaches its optimal point, or is called a moderate point, achievement or performance will reach its maximum point (Broadhurst, 1959). The existence of these stimuli can respond both positively and negatively. When the stimulus has an impact on decreasing performance or performance, it can be said that the stimulus is work stress or stress (Bachroni \& Asnawi, 1999).

In this study, the stimulus given is in the form of time pressure in the audit process. Time pressure has an impact on the work stress perceived by the auditor. In accordance with the inverse $U$ theory, if the stress level is too low, the auditor's work effectiveness (reflected in the resulting audit report) also tends to be low due to the absence of driving forces. At moderate level stress, the driving factor will be in the optimal level and increase the auditor's work effectiveness. Furthermore, at a stress level that is too high, the effectiveness of work is not getting better, but on the contrary, it decreases because the auditor is afraid and too worried that he cannot meet the targets that must be achieved. The more stressed the auditor because the time to complete the audit narrower, the auditor tends to take actions that can cause audit quality to decline (Andreas, 2016; Zakaria, Yahya \& Salleh, 2013).

Based on the description above, the purpose of this study is to empirically examine the effect of independence and audit procedures on audit quality, as well as audit time pressure in moderating the relationship of independence and audit procedures to audit quality. The difference in this study lies in the study sample, namely the auditors in East Java. In addition, the theoretical basis used in the moderating variable is also different 
compared with Halim (2014). This difference in theory is intended to prove empirically whether audit time pressure strengthens or weakens the relationship between the independent variable and the dependent variable.

The theoretical contribution of this research is to provide support for the reverse $U$ work stress theory. Empirical results prove that audit time pressure weakens the relationship between independence and audit procedures to detect fraud on audit quality. When auditors experience a high level of stress due to the limited time of the audit, this will cause disruption of independence and failure to carry out audit procedures to detect fraud so that the resulting audit can decline in quality. Furthermore, practical contributions especially for policy makers. The results of this study can be a consideration for regulators in the formulation of policies and regulations relating to audits. Especially in terms of making a special agency in assessing the independence of auditors. In addition, the regulator can adopt SAS 99 into SPAP for audit procedures in order to detect fraud in the financial statements appropriately.

\section{Literature Review and Hypotheses Development}

\section{Independence of Audit Quality}

The work stress theory described by the inverted $U$ explains that the pressure felt by someone can have an impact on increasing performance or vice versa. The work stress theory described by the inverse $U$ explains that the pressure felt by someone can have an impact on increasing performance or vice versa. The pressure that is too low or too high will make the performance decreases (Jum'ati \& Wuswa, 2013). One of the pressures faced by auditors is time pressure. The auditor is required to complete the work within the time set out in the audit plan. This time pressure is the cause of work stress. In this regard, the auditor is required to be able to complete the audit work without being influenced by time constraints and influence from the management. Thus, auditor is expected to be able to maintain independence, so that the resulting audit is of high quality. This is supported by Umar and Anandarajan (2004) which confirms that reduced audit quality is due to reduced auditor independence. Several previous studies have discussed the positive relationship of independence to audit quality (Rahmina \& Agoes, 2014; Sarwoko \& Agoes, 2014; Tepalagul \& Lin, 2015; Garcia-Blandon \& Argiles, 2015; Halim, 2014). The higher the independence of public accountants, the higher the quality audit will be.

Based on these explanation, the researcher argues that when the auditor chooses to maintain his mental attitude from various things that can interfere with his independence, the resulting audit reflects the actual situation, so that the resulting audit can provide sufficient confidence that financial statements are free from material misstatements. However, if the opposite, the auditor cannot maintain its independence, it can affect audit results that are not qualified. Thus, the hypothesis is formulated as follows:

$H_{1}$ : Independence has a positive effect on audit quality. 


\section{Audit Procedure for Detecting Fraud of Audit Quality}

The audit procedure emphasized in this study is an audit procedure to detect fraud in financial statements. SAS 99 contains an expansion of audit procedures in an effort to detect fraud (Kassem \& Higson, 2012; Carpenter, 2007) to improve audit practices (Trongmateerut, 2011). Trongmateerut (2011) also explained that SAS 99 gives more attention to fraud and the risk of fraud in the audit process than SAS 82. Previous research (Sarwoko \& Agoes, 2014; Trongmateerut, 2011; Kassem \& Higson, 2012; Koroy, 2009; Sarwoko, 2014) have discussed audit procedures to detect fraud, in relation to audit quality. The results of all the studies mentioned earlier indicate that audit procedures have a significant positive relationship to audit quality.

Researchers also have the same understanding as the results of previous studies. If the auditor can adopt SAS No. 99 in order to carry out audit procedures to detect fraud in the financial statements, the possibility of material misstatement in the financial statements is also smaller. The smaller the possibility of material misstatement, the more audit results can be said to be of higher quality. Audited financial statements can be used as a tool for taking decisions by stakeholders. So that it can be said that:

$\mathrm{H}_{2}$ : Audit procedures have a positive effect on audit quality.

\section{Audit Time Pressure weakens the relationship between Independence and Audit Quality}

Time pressure is closely related to the work stress theory (Zakaria et al., 2013; Simanjuntak, 2008). Bachroni and Asnawi (1999) explain that one source of stress originating from the organization is the task demand. In this case, the auditor is required to complete the work, namely the audit within a predetermined period of time. As it is known that in the initial stage of the audit planning stage, the auditor must determine how long it will take to complete the audit. It can be said that the auditor must complete the audit work within a predetermined period of time.

The tightness of time occurs when a set of targets seems difficult to achieve due to limited time. Auditors see time as a performance indicator, so that it increases stress for auditors (Zakaria et al., 2013). Most auditors experience stress at a high level and result in dysfunctional behavior. Dysfunctional behavior causes low quality audits. Coram, Ng and Woodliff (2004) explain that there is a high audit time pressure, causing the auditor to receive audit evidence that is doubtful and ignores risks. This kind of thing causes the detection of material misstatement contained in the financial statements. DeAngelo (1981) states that the possibility of auditors not reporting any material misstatement depends on auditor independence. So, it can be said that if the audit time pressure causes the auditor to not be able to report misstatements, then the tight time of the audit causes the auditor unable to maintain its independence. This of course will cause a decrease in audit quality. Based on this explanation, it can be formulated: 
$H_{3}$ : Audit time pressures weaken the relationship between independence and audit quality.

\section{Audit Time Pressure weakens the relationship between Audit Procedures and Audit Quality}

Otley and Pierce (1996) explain that auditor is faced with increasing competition, resulting in a cost quality dilemma. Auditors must be able to reduce the time of work so that the costs incurred can be minimized, so that they can compete in determining the audit fee. In order to set the time for work, the auditor makes the audit time so that the audit can be completed within a period of time that is not detrimental in terms of cost. But if at that time, the auditor cannot complete his work, then the dysfunctional behavior is that all audit procedures are not carried out (premature audit sign off).

Soobaroyen and Chengabroyan (2006) state that auditor faces a dilemma, namely the pressure to reduce costs by completing a limited time audit, but on the other hand the auditor must maintain a professional standard by not taking actions that can reduce audit quality. Audit time pressure causes the auditor to perform audit procedures imperfectly (premature audit sig off). Shapeero, Chye Koh and Killough (2003) asserted that premature audit sign off directly causes the quality of audit produced to decrease and this action is contrary to professional standards. Based on this explanation, it can be formulated:

$\mathrm{H}_{4}$ : Audit time pressure weakens the relationship between audit procedures and audit quality.

Based on hyphoteses developed, the research model was formulated as shown in Figure 1.

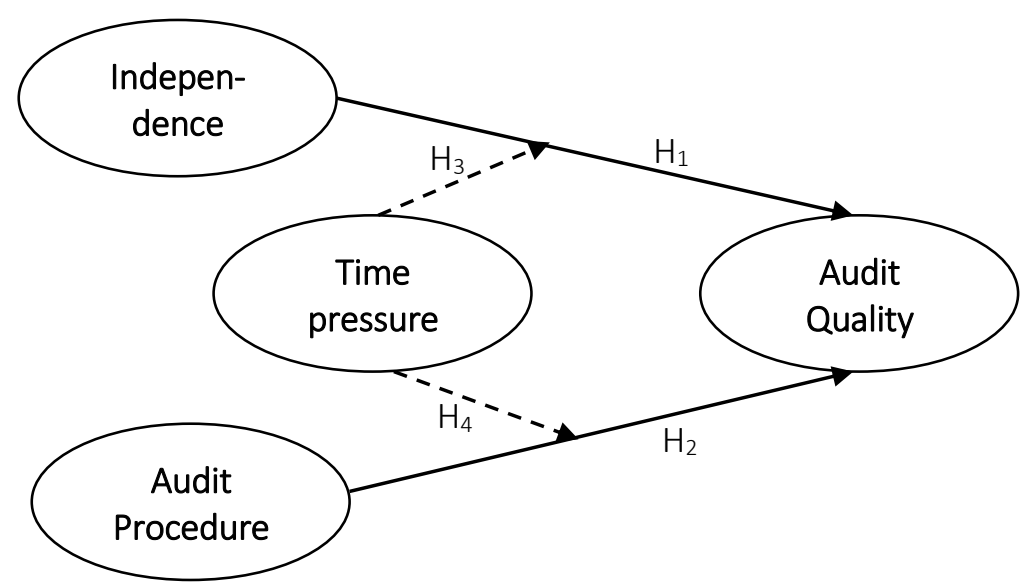

Figure 1. Research Model 


\section{Research Method}

The population in this study were auditors who worked at the Public Accounting Firm (KAP) in East Java. The reason for choosing auditors in East Java is based on the official website www.iapi.or.id, the second largest number of KAP in Indonesia after Jakarta is East Java, so researchers assume that the second highest number of auditors after Jakarta is East Java. The sampling technique was done by nonprobability, namely convenience sampling. The reason for using convenience sampling technique is consideration of convenience because respondents, namely auditors, are people who have a relatively high level of activity.

This research uses survey techniques as a data collection technique. The distribution of questionnaires for KAP in the areas of Surabfaya, Sidoarjo, and Pasuruan was sent via mail, and came to the KAP in Malang. The total questionnaire distributed as a whole was 72 questionnaires but which returned and could be processed as many as 45 questionnaires. So that the total sample in this study was 45 .

The construct in this study consists of independence, audit procedures, audit time pressure, and audit quality. Audit time pressure is a moderating variable in this research. The construct or also called latent variable is variable that can not be measured directly (Jogiyanto \& Abdillah, 2009). All contracts in this study were measured using a five-point Likert scale starting from strongly disagree to strongly agree. The use of a five-point Likert scale is based on consideration of the auditor's busy life. It is expected that with the use of five points, the questionnaire looks simpler so the auditor is willing to fill out the questionnaire.

Independence is a relationship between auditors and clients that is neutral, and cannot be influenced by anything except evidence found and collected in accordance with professional rules and principles (Rahmina \& Agoes, 2014). This study uses the Antle (1984) research indicator adapted by Rahmina and Agoes (2014), and combines indicators of independence from Halim (2014) which is adopted from Beattie, Brandt and Fearnley (1999). The reason for combining indicators is to better describe the latent variables of independence more fully.

Audit procedures are procedures used to detect fraud risks in financial statements so that high quality audits can be produced (Sarwoko \& Agoes, 2014). The indicators and items used in this study were taken from the research of Sarwoko and Agoes (2014). Audit quality is a market assessment that is associated with opportunities given to the auditor to find violations in the client's accounting system and report such violations (DeAngelo, 1981). The indicators used in this study are indicators used by Sarwoko and Agoes (2014). Audit time pressure is a situation where the auditor is required to complete the audit on time with the time that has been prepared and is very strict with the aim of audit time efficiency (Otley \& Pierce, 1996). The indicators used in this study are indicators used by Otley and Pierce (1996) and Halim (2014). 
This study uses Structural Equation Model-Partial Least Square (SEM-PLS) in analyzing data and testing hypotheses. The main reason the researchers used SEM-PLS as an analytical tool because SEM was able to analyze variables that could not be measured directly or had to use indicators or questionnaire questions (Sholihin \& Ratmono, 2013). Data analysis in this study consisted of descriptive statistics, data quality tests which included outer and inner models, and hypothesis testing.

\section{Result and Discussion}

\section{Response rate}

This study uses a sample of auditors working in KAP in East Java. Questionnaires that returned and could be processed were 45 (62\%) with details in Table 1. Not all returned questionnaires can be processed. This is because respondents are less serious in filling out the questionnaire. The inconsistency in the answers to the two negative statements with positive statements is evidence of respondents' seriousness. Questionnaires that cannot be processed are also caused by items that are not filled.

Test Results of the Measurement Model (Outter Model) Construct Validity Test Results

The construct validity test consists of convergent validity test and discriminant validity test. Table 2 presents the results of the convergent validity test and discriminant validity. Based on table 2 it can be concluded that all indicators have met the construct validity requirements. Furthermore, the highest loading value collects at each specified construct. This shows that these indicators have met the discriminant validity requirements. Based on Table 2 , all instruments are reliable. This is indicated by the cronbach's alpha value greater than 0.6 and the composite reliability greater than 0.7 .

\section{Discussion}

Table 3 shows hypotheses testing result summary. Empirical evidence shows that audit quality is influenced by independence. This empirical evidence is in line with research conducted by Rahmina and Agoes (2014), Tepalagul and Lin (2015), Sarwoko and Agoes (2014), and Sudarna and Ludigdo (2014). Research on independence and audit quality was also carried out by Tepalagul and Lin (2015). Broadly speaking, four things are grouped that can threaten the independence of auditors, namely important clients, non-audit services, tenure audits, and clients affiliated with KAP. The results of the

Table 1 Questionnaire Return Rate

\begin{tabular}{lcc}
\hline Information & Total & Percentage (\%) \\
\hline Distributed Questionnaire & 72 & 100 \\
Questionnaire that doesn't return & 24 & 34 \\
Return Questionnaire & 48 & 66 \\
Questionnaire that cannot be processed & 3 & 4 \\
Questionable questionnaire & 45 & 62 \\
\hline
\end{tabular}


research by Tepalagul and Lin (2015) explain the findings related to incentives, perceptions, and behavior of auditors and clients. Any threats to independence will affect the quality of the resulting audit and financial statements. Auditor independence is important because independence influences audit quality. If the auditor does not pay attention to independence, there will be a tendency not to report irregularities in the financial statements, which can damage audit quality.

In line with the above research, Sarwoko and Agoes (2014) used fifty Public Accounting Firms registered in the Indonesian capital market as a population. However, respondents in this study were only audit partners. The measurement of the independence variable in the study is based on mental attitude, and is divided into three stages: first the planning stage, the second implementation stage, and the three audit reporting stages. The results of the study explain that the effect of independence on audit quality is positive. This shows that the higher the independence of the auditor, the higher the quality audit produced.

The research of Sudarna and Ludigdo (2014) also prove that independence has a positive effect on audit quality. However, this research was conducted in the public sector. The population used was all the teams that formed to carry out the 2010 LKPD examination of 497 audit teams at six BPK RI representative offices in Jakarta, Serang, Bandung, Yogyakarta, Semarang, and Surabaya. Independence in the study was measured using the length of the relationship with the auditee, the provision of non-audit services, pressure from the auditee, and review of fellow auditors.

Several studies, both conducted on auditors working at the Public Accountant Office and BPK RI, proved that the higher the auditor's independence, the higher the quality of the audit produced. Current research shows the same results as previous studies. This proves that auditor independence has a positive effect on audit quality. Furthermore, empirical evidence shows that audit procedures have a positive effect on audit quality. This result is consistent with the research conducted by Sarwoko (2014) and Sarwoko and Agoes (2014). Sarwoko (2014) and Sarwoko and Agoes (2014) provide empirical evidence that audit procedures have a positive effect on audit quality. The audit procedures in both studies were measured using three indicators, ie first not implementing minimum procedures contained in SA Section 316 SPAP, both implementing minimum SPAP procedures, and third implementing minimum SPAP procedures plus audit procedures contained in SAS 99 AICPA. The three indicators focus on audit procedures that are used to detect misstatements caused by error and fraud. The three indicators focus on audit procedures that are used to detect misstatements caused by fraud and fraud. The implementation of audit procedures that are focused on detecting misstatements because the auditor has not fully complied with audit standards, especially audit procedures, resulting in audit failure cases.

The audit procedure used in the present research is also an audit procedure to detect the occurrence of misstatements due to errors and fraud. Empirical evidence shows the same results, namely audit procedures have a positive effect on audit quality. This shows that the more detailed audit procedures used by auditors in detecting fraud, the higher the audit 
Table 2 Test Result of Construct Validity and Reliability

\begin{tabular}{|c|c|c|c|c|c|c|}
\hline Construct & Indicator & $\mathrm{AVE}$ & Loading Value & Cross Loading & Significance & Conclusion \\
\hline \multirow{10}{*}{ Independence } & Al1 & \multirow{10}{*}{0.564} & 0.689 & $<0.689$ & $<0.001$ & Valid \\
\hline & $\mathrm{Al} 2$ & & 0.820 & $<0.820$ & $<0.001$ & Valid \\
\hline & $\mathrm{Al} 3$ & & 0.829 & $<0.829$ & $<0.001$ & Valid \\
\hline & Al4 & & 0.779 & $<0.779$ & $<0.001$ & Valid \\
\hline & Al5 & & 0.766 & $<0.766$ & $<0.001$ & Valid \\
\hline & Al6 & & 0.740 & $<0.740$ & $<0.001$ & Valid \\
\hline & Al7 & & 0.718 & $<0.718$ & $<0.001$ & Valid \\
\hline & Al8 & & 0.755 & $<0.755$ & $<0.001$ & Valid \\
\hline & Al9 & & 0.685 & $<0.685$ & $<0.001$ & Valid \\
\hline & Al10 & & 0.713 & $<0.713$ & $<0.001$ & Valid \\
\hline \multirow{3}{*}{$\begin{array}{l}\text { Audit } \\
\text { Procedure }\end{array}$} & AP1 & \multirow[t]{3}{*}{0.727} & 0.854 & $<0.854$ & $<0.001$ & Valid \\
\hline & AP2 & & 0.910 & $<0.910$ & $<0.001$ & Valid \\
\hline & AP3 & & 0.789 & $<0.789$ & $<0.001$ & Valid \\
\hline \multirow[t]{20}{*}{ Audit Quality } & $\mathrm{AQ1}$ & \multirow{20}{*}{0.717} & 0.812 & $<0.812$ & $<0.001$ & Valid \\
\hline & AQ2 & & 0.887 & $<0.887$ & $<0.001$ & Valid \\
\hline & AQ3 & & 0.780 & $<0.780$ & $<0.001$ & Valid \\
\hline & AQ4 & & 0.795 & $<0.795$ & $<0.001$ & Valid \\
\hline & AQ5 & & 0.868 & $<0.868$ & $<0.001$ & Valid \\
\hline & AQ6 & & 0.835 & $<0.835$ & $<0.001$ & Valid \\
\hline & AQ7 & & 0.857 & $<0.857$ & $<0.001$ & Valid \\
\hline & AQ8 & & 0.857 & $<0.857$ & $<0.001$ & Valid \\
\hline & AQ9 & & 0.867 & $<0.867$ & $<0.001$ & Valid \\
\hline & AQ10 & & 0.795 & $<0.795$ & $<0.001$ & Valid \\
\hline & AQ11 & & 0.950 & $<0.950$ & $<0.001$ & Valid \\
\hline & $\mathrm{AQ12}$ & & 0.909 & $<0.909$ & $<0.001$ & Valid \\
\hline & $\mathrm{AQ13}$ & & 0.862 & $<0.862$ & $<0.001$ & Valid \\
\hline & AQ14 & & 0.792 & $<0.792$ & $<0.001$ & Valid \\
\hline & AQ15 & & 0.842 & $<0.842$ & $<0.001$ & Valid \\
\hline & AQ16 & & 0.870 & $<0.870$ & $<0.001$ & Valid \\
\hline & $\mathrm{AQ17}$ & & 0.887 & $<0.887$ & $<0.001$ & Valid \\
\hline & AQ18 & & 0.859 & $<0.859$ & $<0.001$ & Valid \\
\hline & AQ19 & & 0.841 & $<0.841$ & $<0.001$ & Valid \\
\hline & $\mathrm{AQ} 20$ & & 0.749 & $<0.749$ & $<0.001$ & Valid \\
\hline \multirow[t]{4}{*}{ Time Pressure } & TP1 & \multirow[t]{4}{*}{0.610} & 0.745 & $<0.745$ & $<0.001$ & Valid \\
\hline & TP2 & & 0.823 & $<0.823$ & $<0.001$ & Valid \\
\hline & TP3 & & 0.781 & $<0.781$ & $<0.001$ & Valid \\
\hline & TP4 & & 0.774 & $<0.774$ & $<0.001$ & Valid \\
\hline \multicolumn{2}{|c|}{ Variable } & \multicolumn{2}{|c|}{ Cronbachs Alpha } & \multicolumn{2}{|c|}{ Composite Reliability } & Conclusion \\
\hline \multicolumn{2}{|c|}{ Auditor Independence } & \multicolumn{2}{|c|}{0.913} & \multicolumn{2}{|c|}{0.928} & Reliable \\
\hline \multicolumn{2}{|c|}{ Audit Procedure } & \multicolumn{2}{|r|}{0.810} & \multicolumn{2}{|c|}{0.888} & Reliable \\
\hline \multicolumn{2}{|l|}{ Audit Quality } & \multicolumn{2}{|r|}{0.979} & \multicolumn{2}{|c|}{0.981} & Reliable \\
\hline \multicolumn{2}{|l|}{ Time Pressure } & \multicolumn{2}{|r|}{0.786} & \multicolumn{2}{|c|}{0.862} & Reliable \\
\hline
\end{tabular}

Information: Al: Auditor Independence, AP: Audit Procedure, AQ: Audit Quality, TP: Time Pressure

produced. The audit procedure found in SAS 82 AICPA adopted into SA Section 316 SPAP, is less effective in detecting fraud in financial statements. In response, in 2002 AICPA published SAS 99 which contains rules regarding audit procedures that are more detailed to detect fraud, such as brain storming and red flag procedures. Audit procedures for detecting fraud found in SAS 99 is an improvement in audit procedures found in SAS 82 AICPA. 
Table 3 Result of Hypothesis Test

\begin{tabular}{cccccc} 
Hypothesis & Explanation & $\begin{array}{c}\text { Value of } \\
\text { Coefficient Path }\end{array}$ & $\begin{array}{c}\text { Significance Value } \\
\text { (one-tailed) }\end{array}$ & $\begin{array}{c}\text { Positive/Negative } \\
\text { Significance }\end{array}$ & Yes/No \\
\hline $\mathrm{H}_{1}$ & $\mathrm{Al} \rightarrow \mathrm{AQ}$ & 0.627 & $<0.0005$ & $\begin{array}{c}\text { Positive, } \\
\text { significance } \\
\text { Positive, } \\
\text { significance }\end{array}$ & Yes \\
$\mathrm{H}_{3}$ & $\mathrm{AP} \rightarrow \mathrm{AQ}$ & 0.372 & 0.0050 & $\begin{array}{c}\text { Negative, } \\
\text { significance } \\
\text { Positive, } \\
\text { significance }\end{array}$ & Yes \\
$\mathrm{H}_{4}$ & $\mathrm{Al}{ }^{*} \mathrm{TP} \rightarrow \mathrm{AQ}$ & -0.261 & 0.0200 & 0.0500 & Yes \\
\hline
\end{tabular}

Information: Al: Auditor Independence, AP: Audit Procedure, AQ: Audit Quality, TP: Time Pressure

Based on the results of testing, time pressure weakens the relationship between independence and audit quality. This shows that the greater the time pressure experienced by the auditor, the auditor's independence becomes disrupted and results in a decrease in the quality of the audit produced. The results showed that the smaller the time pressure experienced by the auditor, the greater the effect on the ability of the auditor to report the findings of violations in the client's accounting system, so that the resulting audit more qualified. This is because independence is the auditor's ability to report findings of violations (DeAngelo, 1981). There are theoretical differences that underlie the pressure of the current research audit compared with Halim (2014). Current research uses the theory of reverse $U$ work stress, while Halim's uses the theory of affective events.

Job stress theory explains that when the target time gets tighter, performance will increase until time becomes tight and starts to indicate an inability to achieve. After this point, the goal will decrease, so that the presence of an inverse $U$ curve will connect between the tightness of time and a decrease in performance. Current research has obtained empirical evidence that shows that the greater time pressure faced by auditors, the smaller the auditor's ability to report findings of violations and result in lower audit quality produced.

Based on the theory of inverted $U$ work stress, in this study indicate that time pressure makes the auditor unable to achieve quality audit results due to disruption of auditor independence. Many things make auditor independence impaired, such as audit environmental factors, namely the presence of time pressure. In other words, time pressure weakens the relationship of independence and audit quality. This empirical evidence is supported by research conducted by Otley and Pierce (1996), Pierce and Sweeney (2004) and McNamara and Liyanarachchi (2008).

Finally, the results of the study prove that time pressure weakens the relationship between audit procedures and audit quality. The current research provides empirical evidence such as Isrowiyah (2011). The study states that the greater time pressure faced by auditors in carrying out audit procedures, the greater dysfunctional audit actions that lead to decreased audit quality. The empirical evidence explains that time pressure weakens the relationship between audit procedures and audit quality. 
The cause of time pressure reinforcing the relationship between audit procedures and audit quality is experiencing stress caused by the time pressure. The auditor is required to be able to complete his work with a predetermined time. Some studies provide empirical evidence that shows when auditors experience time pressure problems, this will lead to behavior violations (Margheim, Kelley \& Pattison, 2005; Otley \& Pierce, 1996; McNamara \& Liyanarachchi, 2008; Zakaria et al., 2013). The behavioral violations carried out related to the time pressure is that some audit procedures should not be carried out. This causes a material misstatement that cannot be detected so that it can lead to a decrease in audit quality.

\section{Conclusion}

This study aims to provide empirical evidence of the effect of independence and audit procedures on audit quality with audit time pressure as a moderating variable. Respondents who were sampled in this study were as many as 45 auditors who worked for KAP in East Java. PLS SEM is used as a data processor using the Warp PLS 3.0 application. The more independent and applying all audit procedures to detect misstatements, the better the resulting audit. Quality audits can provide actual information, so that it can be used as a decision-making tool for users of financial statements. Furthermore, empirical evidence shows that time pressure weakens the independence relationship, audit procedures to detect fraud and audit quality.

The implication of this research is that it can be a consideration for the auditor when deciding to accept an audit job. This is because in completing the audit, the auditor is limited by time as determined in the planning stage of the audit. The results of the study prove that when auditors face the problem of time pressure, this problem tends to weaken the relationship of independence and audit procedures to audit quality. Time pressure is one of the things that causes work stress for auditors.

The limitation of the study is that it does not distinguish the auditor's stress level at the junior auditor level to the partner. The suggestion for the next research is to divide the auditor level to find out the stress level, so that the auditor can know at what level the highest level of stress when faced with the pressure of the audit time. In addition, subsequent research can use experimental studies to examine factors that influence audit quality. Further researchers can also associate time pressure variables perceived by auditors with deviant actions or dysfunctional behavior.

\section{References}

AICPA. (2014). Error Corrections: Accounting and Reporting Issues. Retrieved from https://www.aicpa.org/search.html?source=AICPA\&q=Auditor + is + res ponsible + for + planning + and + carrying + out + audits + to + obtain + sufficie $\underline{\mathrm{nt}}+$ confidence + whether + the + financial + statements + are + free + from $+\mathrm{m}$ aterial+errors + and + whether + there + are + intentional + or + not + errors + in $+2002$ 
Pusat Pembinaan Profesi Keuangan Sekretariat Jenderal - Kementrian Keuangan. Akuntan Publik yang Dikenakan Sanki Pembekuan Izin. Retrieved from http://pppk.kemenkeu.go.id/Publikasi/Index/11

Amrulloh, A., \& Putra, Y. H. S. (2014). Pengaruh Independensi Dan Pengalaman Auditor Terhadap Kualitas Audit Pada Kantor Akuntan Publik. El Muhasaba: Jurnal Akuntansi, 5(2), 240-258. https://doi.org/10.18860/em.v5i2.2862

Andreas. (2016). Intercation between Time Budget Pressure and Professional Commitment toward Underreporting and Time Behaviour. Procedia Social and Behavioral Sciences, 219, 91-98. https://doi.org/10.1016/i.sbspro.2016.04.047

Ashari, H. (2017). Mitra Ernst \& Young Indonesia didenda US\$ 1 juta. Kontan. Retrieved from https://nasional.kontan.co.id/news/mitra-ernst-youngindonesia-didenda-us-1-juta

Bachroni, M., \& Asnawi, S. (1999). Stres kerja. Buletin Psikologi, 7(2).

Beattie, V., Brandt, R., \& Fearnley, S. (1999). Perceptions of auditor independence: UK evidence. Journal of international accounting, auditing and taxation, 8(1), 67-107. https://doi.org/10.1016/s1061-9518(99)00005-1

Broadhurst, P. (1959). The interaction of task difficulty and motivation: The Yerkes Dodson law revived. Acta Psychologica, 16, 321-338. https://doi.org/10.1016/0001-6918(59)90105-2

Carpenter, T. D. (2007). Audit team brainstorming, fraud risk identification, and fraud risk assessment: Implications of SAS No. 99. The Accounting Review, 82(5), 1119-1140. https://doi.org/10.2308/accr.2007.82.5.1119

Coram, P., Ng, J., \& Woodliff, D. R. (2004). The effect of risk of misstatement on the propensity to commit reduced audit quality acts under time budget pressure. Auditing: A Journal of Practice \& Theory, 23(2), 159-167. https://doi.org/10.2308/aud.2004.23.2.159

DeAngelo, L. E. (1981). Auditor size and audit quality. Journal of accounting and economics, 3(3), 183-199. https://doi.org/10.1016/0165-4101(81)90002-1

Garcia-Blandon, J., \& Argiles, J. M. (2015). Audit firm tenure and independence: A comprehensive investigation of audit qualifications in Spain. Journal of international accounting, auditing and taxation, 24, 82-93. https://doi.org/10.1016/j.intaccaudtax.2015.02.001

Gasperz, J. (2014). Pengaruh Tekanan Anggaran Waktu Sebagai Variabel Moderasi terhadap Hubungan antara Faktor Individu dan Kualitas Audit. Dinamika Akuntansi, Keuangan dan Perbankan, 3, 33-45.

Halim, A. (2014). Anggaran Waktu Audit dan Komitmen Profesional Sebagai V ariabel Moderasi Pengarub Kompetensi dan Independensi Auditor Terbadap Kualitas Audit. Paper was presented at Simposium Nasional Akuntansi XVII, Mataram.

IAPI. (2016). Draf Panduan Indikator Kualitas Audit oada Kantor Akuntan Publik. Jakarta Retrieved from http://iapi.or.id/uploads/article/exposure-draft-panduan-indikatorkualitas-audit-5804a2d00298b.pdf.

Isrowiyah, A. (2011). Pengarub Locus of Control dan Dimensi Komitmen Profesional terbadap Perilaku Audit Disfungsional dengan Tekanan Anggaran Waktu yang Dirasakan sebagai Variabel Intervening.(Studi Empiris pada Auditor. Thesis, Universitas Brawijaya.

Jogiyanto, H., \& Abdillah, W. (2009). Konsep dan aplikasi PLS (Partial Least Square) untuk penelitian empiris. Yogyakarta: BPFE.

Jum'ati, N., \& Wuswa, H. (2013). Stres Kerja (Occupational Stres) yang Mempengaruhi Kinerja Individu pada Dinas Kesehatan Bidang Pencegahan Pemberantasan Penyakit dan Penyehatan Lingkungan (P2PPL) di Kabupaten Bangkalan. Neo-Bis, 7(2), 195-211.

Kassem, R., \& Higson, A. (2012). Financial reporting fraud: are standards' setters and external auditors doing enough?. International Journal of Business 
and Social Science, 3(19), 283-290.

https://doi.org/10.11634/21679606170646

Koroy, T. R. (2009). Pendeteksian Kecurangan (Fraud) Laporan Keuangan oleh Auditor Eksternal. Jurnal Akuntansi dan Keuangan, 10(1), 22-23.

Margheim, L., Kelley, T., \& Pattison, D. (2005). An empirical analysis of the effects of auditor time budget pressure and time deadline pressure. The Journal of Applied Business Research, 21(1), 23-36. https://doi.org/10.19030/jabr.v21i1.1497

McNamara, S. M., \& Liyanarachchi, G. A. (2008). Time budget pressure and auditor dysfunctional behaviour within an occupational stress model. Accountancy Business and the Public Interest, 7(1), 1-43.

Otley, D. T., \& Pierce, B. J. (1996). Auditor time budget pressure: consequences and antecedents. Accounting, Auditing \& Accountability Journal, 9(1), 31-58. https://doi.org/10.1108/09513579610109969

Pierce, B., \& Sweeney, B. (2004). Cost-quality conflict in audit firms: an empirical investigation. European Accounting Review, 13(3), 415-441. https://doi.org/10.1080/0963818042000216794

Pradipta, G. K., \& Budiartha, I. K. (2016). Tekanan Anggaran Waktu Sebagai Pemoderasi Pengaruh Profesionalisme Dan Pengalaman Audit Pada Kualitas Audit. E-Jurnal Akuntansi, 1740-1766.

Priantara, D. (2017). Sudah Ada Auditor, Kenapa Terjadi Fraud? Warta Ekonomi. Retrieved from https://www.wartaekonomi.co.id/read144260/sudah-ada-auditorkenapa-terjadi-fraud.html

Rahmina, L. Y., \& Agoes, S. (2014). Influence of auditor independence, audit tenure, and audit fee on audit quality of members of capital market accountant forum in Indonesia. Procedia-Social and Behavioral Sciences, 164, 324-331. https://doi.org/10.1016/j.sbspro.2014.11.083

Sarwoko, I. (2014). Pengaruh Ukuran Kap Dan Masa Perikatan Audit Terhadap Penerapan Prosedur Audit Untuk Mendeteksi Risiko Kecurangan Dalam Laporan Keuangan, Serta Implikasinya Terhadap Kualitas Audit (Survei Pada Kantor Akuntan Publik Anggota Forum Akuntan Pasar Modal). Jurnal Akuntansi, 18(1).

Sarwoko, I., \& Agoes, S. (2014). An empirical analysis of auditor's industry specialization, auditor's independence and audit procedures on audit quality: evidence from indonesia. Procedia-Social and Behavioral Sciences, 164, 271-281. https://doi.org/10.1016/j.sbspro.2014.11.077

Septriani, Y. (2012). Pengaruh Independensi Dan Kompetensi Auditor Terhadap Kualitas Audit, Studi Kasus Auditor Kap Di Sumatera Barat. Jurnal Akuntansi \& Manajemen, 7(2), 78-100.

Shapeero, M., Chye Koh, H., \& Killough, L. N. (2003). Underreporting and premature sign-off in public accounting. Managerial auditing journal, 18(6/7), 478-489.

Sholihin, M., \& Ratmono, D. (2013). Analisis SEM-PLS dengan WarpPLS 3.0 untuk Hubungan Nonlinier dalam Penelitian Sosial dan Bisnis. Yogyakarta: Penerbit Andi.

Simanjuntak, P. (2008). Pengarub Time Budget Pressure Dan Resiko Kesalahan Terhadap Penurunan Kualitas Audit (Reduced Audit Qaulity)(Studi Empiris Pada Auditor Kap Di Jakarta). Thesis, Universitas Diponegoro.

Soobaroyen, T., \& Chengabroyan, C. (2006). Auditors' Perceptions of Time Budget Pressure, Premature Sign Offs and Under-Reporting of Chargeable Time: Evidence from a Developing Country. International Journal of Auditing, 10(3), 201-218. https://doi.org/10.1111/j.10991123.2006.0350.x

Sudarna, M., \& Ludigdo, U. (2014). Pengaruh Kompetensi, Independensi Dan Ukuran Auditee Terhadap Kualitas Audit. El Mubasaba: Jurnal Akuntansi, 5(2), 226-239. https://doi.org/10.18860/em.v5i2.2861 
Tepalagul, N., \& Lin, L. (2015). Auditor independence and audit quality: A literature review. Journal of Accounting, Auditing \& Finance, 30(1), 101-121. https://doi.org/10.1177/0148558x14544505

Trongmateerut, P. (2011). The Impact of Assessment Procedures and Need for Cognition on Fraud Risk Assessments. Retrieved from https://research.libraries.wsu.edu/xmlui/handle/2376/2847

Umar, A., \& Anandarajan, A. (2004). Dimensions of pressures faced by auditors and its impact on auditors' independence: a comparative study of the USA and Australia. Managerial auditing journal, 19(1), 99-116. https://doi.org/10.1108/02686900410509848

Wijono, S. (2010). Psikologi industri dan organisasi: dalam suatu bidang gerak psikologi sumber daya manusia. Jakarta: Kencana.

Zakaria, N. B., Yahya, N., \& Salleh, K. (2013). Dysfunctional Behavior among Auditors: The Application of Occupational Theory. Journal of Basic and Applied Scientific Research, 3(9), 495-503. 